\title{
Medical Students' Perception Regarding E- Learning during Covid-19 Lockdown Period
}

\author{
Pratibha Manandhar, ${ }^{1}$ Naresh Manandhar, ${ }^{1}$ Sunil Kumar Joshi'
}

'Department of Community Medicine, Kathmandu Medical College, Duwakot, Bhaktapur, Nepal.

\begin{abstract}
Introduction

Due to Covid-19 lockdown period undergraduate medical institutions across the country are moving towards e-learning for continuity of education. The purpose of this study is to determine the perceptions of students towards e-learning and to analyze medical students' perception on e-learning vs. conventional learning.
\end{abstract}

\section{Methods}

This was a descriptive cross sectional study conducted by distributing an online semi-structured questionnaire consisting Likert scale to undergraduate medical students of Kathmandu Medical College. Data assembled from the survey were analyzed and Statistical package for social sciences (SPSS) 24 version software was used for data analysis.

\section{Results}

A total of 273 students were enrolled in this study. Most of the students, $83.9 \%$ (229) had the perception that conventional teaching method was the best method for learning as compared to e-learning method $16.1 \%$ (44). The students mentioned that conventional method of learning is more effective to increase knowledge than e -learning $(\mathrm{M}=3.87, \mathrm{M}=2.80)$ which was statistically significant $(\mathrm{p}=0.000)$.

\section{Conclusions}

E-learning was the only option for students to study during lockdown period. But students preferred conventional method of learning as compared to e-learning. It might be due to some disadvantages of e-learning, eg. Technical difficulties, lack of interaction with teacher and patients, etc. So, these measures have to be addressed for improving e-learning for betterment of teachinglearning activity during these types of circumstances in future.

Keywords: Covid-19, conventional learning method; e-learning method; students' perception.

Correspondence: Dr. Pratibha Manandhar, Department of Community Medicine, Kathmandu Medical College, Duwakot, Bhaktapur, Nepal. Email: pratibhamanandhar@gmail.com. Phone: +977-9803812216. 


\section{INTRODUCTION}

Over the past several years due to development of information technology in the world, e-learning has been integrated for education and training. ${ }^{1}$ "E-learning" define as instruction delivered electronically via the internet and multimedia and e-learning (online learning through internet) is often identified with web-based learning. ${ }^{2}$ The role of e-learning for students has gained importance considering Covid-19 (corona virus disease -19) pandemic causing most of the educational institutions in the world to close down giving rise to multiple challenges on continuity of education system. ${ }^{3}$ So, most of the academic institutions across the country are moving towards e-learning and would be interesting to explore whether the students are tuned to this new methodology or not. $^{4-6}$ Online classes have some limitations like poor internet connection quality, insufficient digital skills of the respondents whereas time flexibility for the students who have difficulty in physical attendance could be the advantage.$^{7-10}$ So, the main objective of this study was to analyze students' perception on e- learning as compare to conventional learning (face to face learning at school with physical presence).

\section{METHODS}

This was a descriptive cross sectional study conducted among MBBS (Bachelor of Medicine and Bachelor of Surgery) students of Kathmandu Medical College. Ethical clearance for the study was received from Institutional Review Committee (Ref. no. 0710202001) of Kathmandu Medical College. Data collection was done over onemonth duration $\left(20^{\text {th }}\right.$ October to $19^{\text {th }}$ November 2020). Sample size calculation was done by applying formula $\mathrm{N}=\mathrm{z}^{2} \mathrm{pq} / \mathrm{d}^{2}$ with negative prevalence $(p)$ for perception of e-learning was $77 \%{ }^{11}$ with $5 \%$ error and a total sample size estimated was 273 students. Questionnaire was prepared in Google Forms and was distributed to respective MBBS class students ( $1^{\text {st }}$ to $5^{\text {th }}$ year) via class representative through Viber group. The introduction along with the objective of this study was mentioned on the first page of the form and anonymity of the subjects filling form was assured. Those who were willing to take part in the survey needed to tick on the option that they agree to participate in the study after which only the questionnaire page is displayed.

The questionnaire consisted of four parts. In the first part, students were asked to enter their demographic details (age, gender, year of study) and state whether they had previously participated in any online courses or not. In the second part, students were given questions regarding the advantages and disadvantages of e-learning, from which they could choose as many as were true for them. In the third part, students have to rate the e- learning using the Likert scale from 1 to 5 ( 1 = definitely ineffective, 5 = definitely effective). Students were also asked to rate their activity during classes ( $1=$ extremely inactive, 5 = extremely active). ${ }^{12}$ In fourth part, students were asked about the experience of conventional examination (Physical presence at the college in front of examiner) and online examination done via Avyaash software. In the same part, students were asked to rate the level of enjoyment of online classes during lockdown using the Likert scale from 1 to 5 ( 1 = extremely un-enjoyable, 5 = extremely enjoyable). As there is a noticeable difference between the amount and pattern of clinical classes taken in Basic year $\left(1^{\text {st }}\right.$ and $2^{\text {nd }}$ year $)$ from Clinical year $\left(3^{\text {rd }}, 4^{\text {th }}\right.$ and $5^{\text {th }}$ year) at the Medical College, responses between these two groups of students were compared.

Data assembled from the survey was analyzed and for data analysis Statistical package for social sciences (SPSS) 24 version software was used. Categorical variables are presented as frequency and percentage and continuous data are presented as mean. Cross tabulation with Pearson's Chi- 
square test was applied to assess the statistical significance of advantages, disadvantages, effectiveness, participation, acceptance, perception and enjoyment of e-learning. P value $<0.05$ was considered as statistically significant.

\section{RESULTS}

Out of 273 students, $53.1 \%$ (145) were boys and the mean age of the student was $21.86 \pm 2.03$ years. (1830). A total of $26.4 \%$ (72) students had previous experience with e-learning. However, 73.6\% (201) had no previous experience so far. Most of the students $83.9 \%$ (229) liked the conventional method of teaching as the best method for learning whereas only $16.1 \%$ (44) students had chosen elearning. During e-learning, 74\% (202) students had experience of facing technical difficulties sometimes, $24.5 \%$ (67) had faced always and only $1.5 \%$ (4) students had never faced any problems. (Table 1)

\begin{tabular}{|c|c|c|}
\hline \multirow[t]{4}{*}{1} & Gender & No $(\%)$ \\
\hline & Male & $146(53.5)$ \\
\hline & Female & $127(46.5)$ \\
\hline & Total & $273(100)$ \\
\hline \multirow[t]{4}{*}{2} & \multicolumn{2}{|l|}{ Age } \\
\hline & $18-20$ & $17(28.2)$ \\
\hline & $21-30$ & $196(71.8)$ \\
\hline & Total & $273(100)$ \\
\hline \multirow[t]{7}{*}{3} & \multicolumn{2}{|l|}{ Year } \\
\hline & $1^{\text {st }}$ Year & 79 (28.9) \\
\hline & $2^{\text {nd }}$ Year & $30(11.0)$ \\
\hline & $3^{\text {rd }}$ Year & 79 (28.9) \\
\hline & $4^{\text {th }}$ Year & $7(2.6)$ \\
\hline & $5^{\text {th }}$ Year & $78(28.6)$ \\
\hline & Total & $273(100)$ \\
\hline \multirow[t]{4}{*}{4} & \multicolumn{2}{|c|}{ Previous experience on e- learning } \\
\hline & Yes & $72(26.4)$ \\
\hline & No & $201(73.6)$ \\
\hline & Total & $273(100)$ \\
\hline \multirow[t]{4}{*}{5} & \multicolumn{2}{|c|}{ Best method for learning } \\
\hline & Traditional method & $229(83.9)$ \\
\hline & E -learning & $44(16.1)$ \\
\hline & Total & $273(100)$ \\
\hline \multirow[t]{5}{*}{6} & \multicolumn{2}{|c|}{ Ever faced technical difficulties } \\
\hline & Sometime & $202(74.0)$ \\
\hline & Always & $67(24.5)$ \\
\hline & Never & $4(1.5)$ \\
\hline & Total & $273(100)$ \\
\hline
\end{tabular}


Advantages and disadvantages of e-learning method

Ability to record the material for future was the major e-learning advantage chosen by $67.4 \%(184)$ of the students $(\mathrm{p}=0.013)$ followed by access to online materials $56 \%$ (153) and ability to interact in classes $53.1 \%$ (145). While analyzing the disadvantages of e-learning, lack of interaction with patients $74.7 \%$ (204) was chosen as the major disadvantage by the students $(p=0.000)$, followed by lack of interaction with teacher $57.8 \%$ (158) ( $p$ $=0.001$ ) and lack of self-discipline $57.8 \%$ (158), summarized in Table 2.
2. Student's participation on e-learning: Most of the students mentioned that they can participate very actively in conventional learning $(\mathrm{M}=3.73)$ comparing to e learning $(\mathrm{M}=2.88)(\mathrm{p}=0.024)$

3. Acceptance of e-learning: Most of the participants accepted conventional teaching and learning method more $(\mathrm{M}=3.8)$ as compared to e-learning $(\mathrm{M}=2.8)$ $(\mathrm{p}=0.001)$.

4. Perception of giving examination: Students' perception on giving exam via conventional method was more satisfactory as compared to e-learning

Table2. Advantage and disadvantage of e-learning

\begin{tabular}{|c|c|c|c|c|c|}
\hline \multirow{2}{*}{$\begin{array}{l}\text { Variables } \\
\text { Advantage of e- learning }\end{array}$} & \multicolumn{4}{|c|}{ Students Category } & \multirow[b]{2}{*}{ p value } \\
\hline & & Basic & Clinical & Total & \\
\hline Ability to record material for future & & $(23.4 \%)$ & $120(44 \%)$ & $184(67.4 \%)$ & 0.013 \\
\hline Access to online material & 66 & $(24.1 \%)$ & 87 (31.9\%) & $153 \quad(56 \%)$ & 0.22 \\
\hline Ability to interact in class & 49 & $(18 \%)$ & $96(35.1 \%)$ & $145(53.1 \%)$ & 0.028 \\
\hline \multicolumn{5}{|l|}{ Disadvantage of e- learning } & \\
\hline Lack of interaction with patients & 46 & $(16.8 \%)$ & $158(57.9 \%)$ & $204(74.7 \%)$ & 0.000 \\
\hline Lack of interaction with teacher & 77 & $(28.2 \%)$ & $84(30.7 \%)$ & $161(58.9 \%)$ & 0.001 \\
\hline Lack of self- discipline & 73 & $(26.7 \%)$ & $85(31.1 \%)$ & $158(57.8 \%)$ & 0.013 \\
\hline
\end{tabular}

Comparison of conventional vs. e learning in perception and effectiveness

Table 3 has highlighted the Likert scale rating for various questionnaires as follows:

1. Ability to increase knowledge: The students mentioned that the conventional method of learning is very effective to increase the knowledge than e-learning $(\mathrm{M}=3.87, \mathrm{M}=2.80)(\mathrm{p}=0.000)$.
( $M=2.22, M=3.54$ respectively) ( $p=0.000)$. Students preferred to give exam via conventional method than e-learning method [238 (87.2\%), $35 \quad(12.8 \%)]$ respectively.

5. Enjoying e-learning: During this lockdown period students are somewhat enjoying the e classes $(M=3.54)$ 


\begin{tabular}{|c|c|c|c|c|c|c|c|c|}
\hline & Likert scale rating & 1 & 2 & 3 & 4 & 5 & & \\
\hline S.N. & Questionnaires & n (\%) & n (\%) & n (\%) & n (\%) & n (\%) & Mean & p value \\
\hline \multirow[t]{2}{*}{1} & $\begin{array}{l}\text { Ability to increase } \\
\text { knowledge and } \\
\text { clinical practices via } \\
\text { conventional method }\end{array}$ & $7(2.6 \%)$ & $17(6.2 \%)$ & $58(21.2 \%)$ & $114(41.8 \%)$ & $77(28.2 \%)$ & 3.87 & \multirow[b]{2}{*}{0.000} \\
\hline & $\begin{array}{l}\text { Ability to increase } \\
\text { knowledge and } \\
\text { clinical practices via e } \\
\text { learning }\end{array}$ & $19(7 \%)$ & $90(33 \%)$ & $107(39.2 \%)$ & $41(15 \%)$ & $16(5.9 \%)$ & 2.80 & \\
\hline \multirow[t]{2}{*}{2} & $\begin{array}{ll}\text { Students } & \text { Participation } \\
\text { on } & \text { conventional } \\
\text { method } & \end{array}$ & $5(1.8 \%)$ & $18(6.6 \%)$ & $70(25.6 \%)$ & $132(48.4 \%)$ & $48(17.6 \%)$ & 3.73 & \multirow{2}{*}{0.024} \\
\hline & $\begin{array}{l}\text { Students participation } \\
\text { on e -learning }\end{array}$ & $34(12.5 \%)$ & $63(23.1 \%)$ & $98(35.9 \%)$ & $57(20.9 \%)$ & $21(7.7 \%)$ & 2.88 & \\
\hline \multirow{2}{*}{3} & $\begin{array}{l}\text { Level of acceptance of } \\
\text { conventional method }\end{array}$ & $6(2.2 \%)$ & $13(14.8 \%)$ & $73(26.7 \%)$ & $119(43.6 \%)$ & $63(22.7 \%)$ & 3.80 & \multirow[b]{2}{*}{0.001} \\
\hline & $\begin{array}{l}\text { Level of acceptance of } \\
\text { e- learning }\end{array}$ & $32(11.7 \%)$ & $82(30 \%)$ & $86(31.5 \%)$ & $56(20.5 \%)$ & $17(6.2 \%)$ & 2.79 & \\
\hline \multirow[t]{2}{*}{4} & $\begin{array}{l}\text { Perception of giving } \\
\text { exam via conventional } \\
\text { method }\end{array}$ & $88(32.2 \%)$ & $89(32.6 \%)$ & $56(20.5 \%)$ & $27(9.9 \%)$ & $13(4.8 \%)$ & 2.22 & \multirow[b]{2}{*}{0.000} \\
\hline & $\begin{array}{l}\text { Perception of giving } \\
\text { exam via online }\end{array}$ & $18(6.6 \%)$ & $31(11.4 \%)$ & $72(26.4 \%)$ & $87(31.9 \%)$ & $65(23.8 \%)$ & 3.54 & \\
\hline 5 & $\begin{array}{l}\text { Enjoying of e-learning } \\
\text { during COVID-19 }\end{array}$ & $42(15.4 \%)$ & $48(17.6 \%)$ & $105(38.5 \%)$ & $63(23.1 \%)$ & $15(5.5 \%)$ & 2.85 & \\
\hline
\end{tabular}

\section{DISCUSSION}

Most of the medical colleges of our country were closed due to Covid-19 lockdown. During this pandemic the only way of teaching learning activities was through internet. Most of countries around the world were applying the online method of learning for many years, not only in pandemic. But a lower middle income country like Nepal is probably using e-learning teaching method for the first time due to lockdown. So, perception and experience of students regarding this type of learning will be worthy for future also.

This survey indicated that among 273 students, only $26.4 \%$ (72) students had previous experience with e-learning whereas most of the students $73.6 \%$ (201) had no experience of e-learning at all. Similar findings has been obtained as 89\% BDS (Bachelor of Dentistry) students of Kathmandu University by Gupta A et al study ${ }^{13}$ and $89.5 \%$ MBBS students of Gandaki Medical College, Pokhara by Tuladhar SP et $\mathrm{al}^{14}$ had 
never attended any online classes before the online education started during COVID-19 lock down.

In our study, most of the students $74 \%$ (202) have sometimes faced technical problems during online classes. These technical difficulties were shared by Subedi et al also as more than half of the students $(63.2 \%)$ had electricity problem and $63.6 \%$ had internet problem leading to disturbances in online classes among nursing students in Nepal. ${ }^{15}$ Similar technological problems with connectivity were also faced by students of Ghana during online education in a study done by Henaku et al. ${ }^{16}$ This above statement reflects that technical problems are one of the major hindering factors observed during e-learning. Apart from requiring reliable internet connection for e-learning, students and teaching faculties should also be familiar with the electronic media to conduct e-classes in interactive manner also. ${ }^{17,18}$ In our study, 58.9\% (161) students expressed lack of interaction with teacher as one of the major disadvantages of e-learning. Similar dissatisfaction was expressed by $84 \%$ Pakistani students in Abbasi $\mathrm{S}$ et al study ${ }^{11}$ and $76.9 \%$ Nepalese students in Gupta A et al study. ${ }^{13}$

On comparing conventional with e-learning in perception and effectiveness, our study participants mentioned that the conventional method of learning is more effective to increase knowledge and clinical practices than e-learning $(\mathrm{M}=3.87$ and $\mathrm{M}=2.80$ respectively) ( $\mathrm{p}=0.000)$. Students preferred conventional method of learning being very enjoyable as compared to e-learning. A study done by Sharma $\mathrm{K}$ et al at Chitwan Medical College, Nepal found only $53.5 \%$ of students were satisfied with online learning with almost $30 \%$ giving neutral views and concluded that face-to-face theoretical teaching was valuable for their learning process rather than only virtual learning process through internet in terms of their clinical practices and knowledge. ${ }^{19}$

A similar study done by Dhotre et al among MBBS students of Ashwini Rural Medical College, Maharashtra, India also highlighted 75\% students found traditional teaching-learning method better than online teaching methods during Covid-19 pandemic lockdown. ${ }^{20}$ This might be due to some limitations of e-learning like technical difficulties, lack of self-discipline and less interaction among teaching faculties and students. So, our students' satisfaction rate of online e-learning teaching method is quite lower as compared to other studies, where satisfaction rates have been reported as high as $93.4 \%{ }^{21,22}$

\section{CONCLUSIONS}

It has been found that Nepalese students are comfortable to conventional learning even though magnitude of information technology has been improved a lot in recent years. This study highlighted that probably due to its technical problems, lack of patient exposure, less interaction with teachers and lack of selfdiscipline, our students preferred conventional method as better method of learning as compared to e-learning. E-learning along with practical on virtual patients with avoiding technical problems might be a greater goal for increasing knowledge and skill during these types of circumstances in future.

\section{ACKNOWLEDGEMENTS}

We would like to acknowledge MBBS students of Kathmandu Medical College who voluntarily participated in this survey. At last but not the least, my sincere thanks to Ms. Sneha Manandhar for helping to generate Google Forms for the questionnaires.

Limitations of the study: Since, this is a single institutional study, outcome cannot be generalized. 


\section{REFERENCES}

1. Singh G, O'Donoghue J, Worton H. A study into the effects of e-learning on higher education. Journal of University Teaching \& Learning Practice 2005; 2(1):13-25.

2. Smart KL, Cappel JJ. Students' perceptions of online learning: A comparative study. Journal of Information Technology Education Resarch June 2006; 5(1): 201-19.

3. Adhikari P, Paudel S, Pandey RR, Parajuli A, Pyakuryal A, Agrawal A, et al. Effectiveness of e-learning during the COVID-19 Pandemic among the undergraduate medical students in Nepal: An online survey. Journal of Pharmacy Practice and Community Medicine July- Sept 2020, 6(3):40-43.

4. Maheshwari S, Zheleva B, Rajasekhar $\mathrm{V}$, Batra B. E-teaching in pediatric cardiology: A paradigm shift. Ann Pediatr Cardiol 2015;8(1):10-13.

5. Frehywot S, Vovides $Y$, Talib Z, Mikhail $\mathrm{N}$, Ross $\mathrm{H}$, Wohltjen $\mathrm{H}$ et al. E-learning in medical education in resource constrained low- and middle-income countries. Human Resources for Health 2013; 11(4): 1-15.

6. Niebuhr V, Niebuhr B, Trumble J, Urbani M. Online faculty development for creating e-

learning materials. Edu Health 2014; 27(3):255-61.

7. Dyrbye L, Cumyn A, Day H, Heflin M. A qualitative study of physicians' experiences with online learning in a master's degree program: benefits, challenges and proposed solutions. Medical Teacher 2009; 31(2):40-6.

8. Bediang G, Stoll B, Geissbuhler A, Klohn AM, Stuckelberger A, Nko'o S, et al. Computer literacy and e- learning perception in Cameroon: the case of Yaounde Faculty of Medicine and Biomedical Sciences. BMC Med Edu. 2013;13(57):1-8.

9. Attardi SM, Rogers KM. Design and implementation of an online systemic human anatomy course with laboratory. Anat Sci Educ. 2015; 8(1):53-62.

10. McCann AL, Schneiderman ED, Hinton RJ. E -teaching and learning preferences of dental and dental hygiene students. J Dent Educ. 2010; 74(1):65-78.

11. Abbasi S, Ayoob T, Malik A, Memon SI. Perceptions of students regarding E-learning during Covid-19 at a private medical college. Pak J Med Sci. 2020;36(COVID-19-S4):57-61.

12. Liker R. A technique for the measurement of attitudes. Archives of Psychology; 22(140):1-55.

13. Gupta A, Shrestha RM, Shrestha S, Acharya A, Pandey N. Perception of BDS students of Kathmandu University on online learning during COVID-19 pandemic. Orthodontic Journal of Nepal 2020; 10 (2): 20-29.

14. Tuladhar SP, Pradhan D, Parajuli U, Manandhar P, Subedi N. Study on the effectiveness of online classes for undergraduate medical and dental students of Gandaki Medical College during COVID 19 pandemic period in Nepal. Orthodontic Journal of Nepal, 
2020; 10(2): 30-40

15. Subedi S, Nayaju S, Subedi $S$ et.al. Impact of E-learning during COVID-19 pandemic among nursing students and teachers of Nepal. International Journal of Science \& Healthcare Research. 2020; 5(3): 68-76.

16. Henaku EA. COVID-19: Online learning experience of college students: The case of Ghana. International Journal of Multidisciplinary Sciences and Advanced Technology 2020;1(2): 54-62.

17. Frith $\mathrm{KH}$, Kee CC. The effect of communication on nursing student outcomes in a web-based course. J Nurs Educ. 2003; 42(8):350-8.

18. Lu DF, Lin ZC, Li YJ. Effects of a webbased course on nursing skills and knowledge learning. J Nurse Educ. 2009; 48(2):70-7.
19. Sharma K, Deo G, Timalsina S, Joshi A, Shrestha N, Neupane HC. Online Learning in the face of COVID-19 pandemic: Assessment of students' satisfaction at Chitwan Medical College of Nepal. Kathmandu Univ Med J. 2020; 70(2):38-45.

20. Dhotre PS, Shaikh AK, Dhotre SV, Perspective of medical students on online teaching learning process during COVID-19 pandemic. Indian J health Sci and Biomed Res2020; 13(2): 197-201.

21. Seada AI, Mostafa MF. Students' satisfaction and barriers of e-learning course among nursing students, Mansoura University. World Journal of Nursing Sciences 2017; 3 (3): 170-178.

22. Singh A, Min AK. Digital lectures for learning gross anatomy: A study of their efficacy. Korean Journal of Medical Education. 2017; 29(1):27.

Citation: Manandhar P, Manandhar N, Joshi S. Medical Students' Perception Regarding E- Learning during Covid-19 Lockdown Period JCMS Nepal. 2021; 17(2); $101-8$. 